\title{
Relationship of the Youth Unemployment and Determinants of the Labour Market in the Balkan Countries ${ }^{4}$
}

\author{
Article history: \\ Received: 27 September 2017 \\ Sent for revision: 9 October 2017 \\ Received in revised form: 21 November 2017 \\ Accepted: 21 November 2017 \\ Available online: 25 December 2017
}

\begin{abstract}
Balkan countries are facing with a large number of unemployed young people. There is no doubt that financial crises have the biggest influence on the youth labour market. The remainder of this paper is presenting the research results showing the correlation between the unemployment rate (among youth and adults) and the determinants of the labour market in order to determine whether there is a difference in the impact of labour market indicators on the unemployment rates by gender and age. The study focuses on 11 Balkan countries in the period from 2008 to 2014. The data were collected from the Fraser Institute research specifically from "The Economic Freedom of the World: 2016 Annual Report".
\end{abstract}

Keywords: Labour Market, Youth, Unemployment, Balkan Countries.

\section{Veza nezaposlenosti kod mladih $\mathrm{i}$ indikatora tržišta rada u zemljama Balkana}

Apstrakt: Balkanske zemlje suočavaju se sa velikim brojem nezaposlenih mladih ljudi. Nema sumnje da je najveći uticaj na visoku stopu nezaposlenosti kod mladih imala finansijska kriza. U radu su prikazani rezultati korelacije

\footnotetext{
${ }^{1}$ Institute of economic sciences, Belgrade, Serbia dejana.pavlovic@ien.bg.ac.rs

${ }^{2}$ Institute of economic sciences, Belgrade, Serbia

${ }^{3}$ University of Belgrade, Faculty of Organizational Sciences, Serbia

${ }^{4}$ This paper is a part of research projects numbers 179001, 19015 and 47009 financed by the Ministry of Education, Science and Technological Development of The Republic of Serbia
} 
Pavlović D. et al.: Relationship of the Youth Unemployment and Determinants...

između nezaposlenosti (kod odraslih i kod mladih) i indikatora tržišta rada. Cilj je da se definiše da li postoji razlika u uticaju indikatora tržišta rada na stopu nezaposlenosti prema godinama i polu. Istraživanje se fokusira na 11 zemalja Balkana i prati indikatore za period od 2008. do 2014. godine. Podaci su prikupljeni iz baze "The Economic Freedom of the World: 2016 Annual Report".

Ključne reči: tržište rada, mladi, nezaposlenost, zemlje Balkana.

\section{Introduction}

Youth is the most important stage in the life of any individual. Since the financial crisis outbreak in 2008, the high unemployment rate among young people has been one of the most pressing social problems on a global level. Even in countries that are members of the European Union, the solution of this problem is among their priorities (ILO, 2015). However, in developing countries, such as some Balkan countries, due to the high rate of youth unemployment and lack of jobs, it is not easy to be young. The latest statistics show that more than half of the young population in most of the Balkan countries is unemployed (ILO, 2016) which further affects the increase in the informal employment rate (World Bank, 2016; Statistical Office of the Republic of Serbia, 2015). According to the research conducted in Western Balkan countrieske (Arandarenko, Berlett, 2012), results showed that skilled people who cannot find job in the formal sector accept jobs which are below that corresponding to their qualifications or they work in informal sector.

The objective of this paper is to analyse the relationship between youth unemployment with the determinants of the labour market for 11 Balkan countries (Turkey, Bulgaria, Romania, Greece, Albania, Slovenia, Macedonia, Croatia, Montenegro, Bosnia and Herzegovina, Serbia) from the period of 2008 to 2014, and also to compare with the results of the relationship between the unemployment rate among adults with the determinants of the labour market for 11 Balkan countries using panel regression model. In the paper, it is investigated following question:

- What kind of determinants have the biggest influence on the youth unemployment and the total unemployment in Balkan countries?

The reason of this research is multiple. This paper relates to the research by Bernal-Verdugo et al. (2012). Author's (Bernal-Verdugo et al. 2012) results were based on regression analysis of a larger sample of 97 countries for the period from 1985 to 2008, where authors suggest that the hiring and firing regulation and employment costs have the most significant impact on the unemployment rate. In research in the selection of explanatory variables as 
Pavlović D. et al.: Relationship of the Youth Unemployment and Determinants...

determinants of unemployment, it is used indicators of labour market flexibility proposed by Bernal-Verdugo et al. (2012), contained in the "Economic Freedom" database of the Fraser Institute.

In the paper is analysed the period between from 2008 (when financial crisis started) to 2014. Many authors share the opinion that since 2008, the financial crisis has significantly affected the difficult entry of young people into the labour market (Kellly and McGuinness, 2015), while some authors think that the study of the problem of high unemployment rate among young people was current even before the crisis (Vasile, 2012; Marginean, 2014). In Europe, the economic crisis resulted in major changes in GDP, which more greatly influenced youth unemployment than the general unemployment rate (Marginean, 2014). Focusing on the labour market of the Balkan countries since 2008, or the beginning of the crisis, it is evident that most of the Balkan countries are faced with the problem of high unemployment among young people aged 15 to 24. According to the latest statistics from 2015, the highest rate of youth unemployment was observed in Bosnia and Herzegovina $(62.3 \%)$, followed by Greece (49.8\%), Macedonia (47.3\%) and Serbia (43.2\%). According to the latest statistics from the International Labour Organisation in 2015, among eleven Balkan countries (Turkey, Bulgaria, Romania, Greece, Albania, Slovenia, Macedonia, Croatia, Montenegro, Bosnia and Herzegovina, Serbia), the lowest unemployment rate among young people aged 15 to 24 was recorded in Romania (7\%), Bulgaria (9.2\%) and Slovenia $(9.1 \%)$, which is significantly small percentage compared to the countries of the West Balkan. On the other hand, a certain group of authors came to the conclusion that the crisis has a short-term impact on the rate of unemployment among young people, while the different economic and social factors affect the long-term position of young people in the labour market (Marginean, 2014).

This topic become very popular among researchers that has affected the increase in the number of the scientific papers in this field. A whole range of economic, political and social indicators most directly affect the labour market of a country. One of them is for example professional experience or could be education level. Apart from a small number of vacancies in the market, young people aged 15 to 24 are struggling with the lack of professional experience and low level of education. Low-skilled young professionals have little opportunity to improve their social status and position in the labour market, because employers give priority to previous work experience and higher education (Parey, 2009). Some authors believed that minimum wage has the impact on unemployment (Gorry, 2013). The results of the research conducted by Psacharopoulos (2004) implied that highly educated people have better salaries than employees with lower education. 
Pavlović D. et al.: Relationship of the Youth Unemployment and Determinants...

The paper is focused on the Balkan countries because of a series of changes on the Balkan Peninsula that besides the labour market have affected other sectors of the country's development. Chronologically speaking, the changes in the Balkan Peninsula, from the beginning of the transition to European integration and the financial crisis, have resulted in huge social costs expressed in the increase in poor population, declining employment, increased inequality, deterioration of public services, declining birth rates, increasing crime and armed conflicts. In such circumstances, the young react emotionally to the negative impacts of the crisis, they leave their country, enter into conflicts with the law, drop out of school (Arandarenko, 2011).

The main contribution of paper is to be useful for policy proposals and to show the current state of the labour market in Balkan Peninsula and what kind of determinants have the biggest influence on the unemployment rate among young people and adults. The best evidence will be helpful to design appropriate labour market policy in Balkan countries which will reduce position of young people on the labour market.

The paper has limitations: (i) it is focused on the period between 2008 to 2014 because according to "The Economic Freedom of the World: 2016 Annual Report" there is not statistical data from 2015 for 11 Balkan countries. (ii) Compared with the research by Bernal-Verdugo et al. (2012) it isn't use in the model the indicator of military service and macroeconomic controls (see methodology part).

The paper consists of following parts, the introduction shows the aim of research and explained the reasons why it is decided to investigate the youth labour market and the general labour market in Balkan countries from the period between 2008 and 2014. The second part of the paper provides the literature review on the impact of economic and social factors on the labour market of young people and adults. In Section 3 is the methodology part which analyses the relationship of the unemployment rate among young people and adults with the determinants of the labour market for 11 Balkan countries. The Section 4 is left for discussion and conclusion.

\section{Literature review}

The review of the literature revealed that many political, economic and social factors can affect the high unemployment rate among young people and that the impact depends on a country or region analysed. There is a large number of research literature about the impact of the financial crises on the labour market, especially youth labour market. According to the study conducted by Kelly and McGuinness (2015) in the Republic of Ireland, the economic crisis significantly affected the unemployment rate among young people in the 
Pavlović D. et al.: Relationship of the Youth Unemployment and Determinants...

period from 2006 to 2012 by even $11 \%$, while the unemployment rate among young people rose from $9.9 \%$ to $33 \%$ in 2012. Kelly and McGuinness (2015) used binary probit model. Factors taken into account are: gender, age, nationality, education and geographical location (Dublin). The study concluded that in the period of recession, education and ethnicity significantly affect the rate of unemployment among young people.

Different attitude to the impact of the financial crisis on the labour market was expressed by Margimean (2014), who dealt with the position of young people in post-crisis period in Romania. The author analysed the trends in the rate of unemployment among young people in the period from 2007 to 2013. The study came to the conclusion that the crisis had only a short-term impact on the position of young people in the labour market, while the statistical data showed that the unemployment rate among young people in the pre-crisis period had been significantly higher than the general unemployment rate. Having in mind the impact of social and economic factors on the labour market, education level and trend of migration have a significant impact on the change in the unemployment rate among young people in Romania. The largest migrations in recent years in Romania were recorded in 2012, when more than 140,000 young people left the country (more precisely $5.1 \%$ of young people aged 15-24, and $0.9 \%$ of people aged 25-64) (INS, 2014). Young people in Romania are therefore poorly interested in continuing their education and higher education, so they choose to leave their country, which directly affects the labour market.

Certain authors indicate that social factors such as education and professional training have a significant impact on young people's difficulties in finding jobs. The research results in developed countries imply that professional training and gaining new work experience significantly affect the increase in earnings among young people (Flinn, 2006). Heckman, Lochner \& Taber (1998) believe that the post-school professional development is an essential source of knowledge creation. According to Heckman, Lochner \& Taber (1998) postschool education accounts for $30 \%$ to $50 \%$ of the total knowledge in the modern economy.

The study conducted in the 1980s recognized the correlation between the minimum wage and human capital (Rosen, 1972). The results showed that inexperienced workers without experience are not able to pay for additional training for professional development. In order to gain experience, they retain employment in one segment of the labour market, which leads to job dissatisfaction. According to the research conducted by Gorry (2013), professional experience and the amount of the minimum wage in a country have a great impact on the unemployment rate among young people. He developed a model, which is based on the model by Mortensen and Pissarides (1994), focusing on the impact of economic factors on the rate of 
Pavlović D. et al.: Relationship of the Youth Unemployment and Determinants...

unemployment among young people. The model showed that the minimum wage affects the youth unemployment rate due to the high tax burden. The results of previous studies implied that the increase in earnings in the United States in the period from 2007 to 2009 resulted in an increase in the employment rate among young people aged 15 to 24. Results of comparison between the wages and labour costs in the territory of America and France, showed that if France reduced the amount of taxes on salaries, it would have a significant impact on reduction of the level of unemployment among young people. The same opinion is shared by the authors who believe that the labour costs are a barrier on entry of young people into the labour market in France and Germany (Cahuc et al, 2013). The results of a similar study conducted in Taiwan showed that in the period from 1973 to 2004, the increase in the minimum wage led to an increase in the employment rate among young people, as well as increased participation of young people in the labour market by $0.47 \%$ (Chuang, 2006). Some studies focused on the reduction of labour costs for the low-skilled workforce. Cahus and Carcillo (2012) believed that the reduction of contributions for low-skilled workers will significantly affect the increase in the number of jobs. Zubović, Zdravković and Pavlović (2015) concluded that tax rate on low earnings has the greatest impact on the level of unemployment among young people. According to the research that investigated the Australian youth labour market and the impact of the Global Financial Crisis on youth unemployment, young people lost jobs more rapidly during the crisis and employers stop hiring the new entrants. The results of this research implicated that the high unemployment rate could not be explained by minimum wages (Junankar, 2015). Same opinion shares authors who believed that minimum wages do not lead to increase unemployment (Booth, 2014; Card and Krueger, 1994).

There is not lot of research that investigated labour market of the Balkan countries. Numanović et al. (2016) analysed the key aspects of Active Labour Market Polices and their implementation in three Balkan countries- Albania, Bosna and Herzegovina and Macedonia. They concluded that the level of public expenditure on active labour market polices is a low in Albania, Bosna and Herzegovina and Macedonia, and should be brought closer to the EU average (0,5\% of GDP). Ehrke (2011) investigated Western Balkan countries because of economic transition and large structural changes. He points out that the development of education and the improvement of labour force skills is important factor for economic recovery.

\section{Methodology}

In paper is used the panel regression model associating overall unemployment, i.e. youth unemployment with the determinants of labour 
Pavlović D. et al.: Relationship of the Youth Unemployment and Determinants...

market. The research is based on the research by Bernal-Verdugo et al. (2012), proceeds from static empirical model of the correlation between unemployment and the labour market determinants, which is specified as follows (subscript i refers to country, t refers to year)

$z_{i, t}=\alpha+X_{i, t} \beta+Y_{i, t} \gamma+u_{i, t}$, (1)

where the variables are defined as follows:

$\alpha$ is constant;

$z_{(i, t)}$ is selected indicator of unemployment;

$X_{(i, t)}$ is the vector of labour market determinants;

$Y_{(i, t)}$ is the vector of control variables;

$u_{(i, t)}$ is random error.

The simplest estimation method of panel regression model, known as "pooled" is method of least squares (pooled OLS- Ordinary Least Squares), assumes that the random error meets the following assumptions:

$u_{(i, t)}$ is normally and independently identically distributed with zero expected value and constant variance, $u(i, t) \sim N\left(0, \sigma_{u}{ }^{2}\right)$;

$u_{(i, t)}$ is not correlated with regressors, which can be mathematically represented as a $\mathrm{E}\left(X_{u}\right)=0$, and $\mathrm{E}\left(Y_{u}\right)=0$ (Kiš, Radovanov, 2014).

If these two conditions are met, a comparative and temporal structure of panel data becomes irrelevant from the standpoint of estimation, and the regression model is being estimated by a simple application of the method of least squares, without additional assessment modifications or transformations of data (Kiš, Radovanov, 2014). In further empirical analysis is used the fixed effects model as a more appropriate form of evaluation taking into account the structure of the data at disposal, as well as the number of degrees of freedom during the evaluation.

The empirical analysis was conducted on a sample that includes 11 Balkan countries (Albania, Bosnia, Bulgaria, Croatia, Greece, Macedonia, Montenegro, Romania, Serbia, Slovenia, Turkey), for a period of 7 years, from 2008 to 2014, with a maximum of 77 observations. Out of the indicators of unemployment as the dependent variable, it used the unemployment rate (active population of 15 years of age) and the youth unemployment rate (active population aged 15-24), in three variants, overall, for the male and female population. In the selection of explanatory variables as determinants of unemployment, it used indicators of labour market flexibility proposed by Bernal-Verdugo et al. (2012), contained in the "Economic Freedom" database 
Pavlović D. et al.: Relationship of the Youth Unemployment and Determinants...

of the Fraser Institute. The indicators of labour market flexibility include the following variables:

1. The indicator of the minimum wage as a factor of employment barrier (marked as hd_mw) - higher values imply a lower minimum wage;

2. The regulation of hiring and firing as the employment barrier (marked as $h \_f \_r$ ) - higher values imply greater control in hiring and firing;

3. Centralization of collective bargaining (marked as ccb) - higher values imply a lower degree of centralization in the collective bargaining of salaries;

4. Mandatory employment costs (marked as $h \_r$ ) - higher values imply lower taxes, contributions and other associated costs the employer has to pay for a new employee;

5. Mandatory firing costs (marked as mc_wd) - higher values indicate a lower level of severance and other related costs incurred in dismissals.

\section{Results}

The values of all indicators are standardized, so they range from 0 to 10 . Compared to the original paper, it is omitted from the model the indicator of military service, since the conscription was mainly abolished in the Balkans in the last decade. Bernal-Verdugo et al. (2012) also used a larger number of macroeconomic control variables such as the output gap, the economy openness or the public sector size. Given the relatively small sample of a maximum of 77 observations, the paper provides the estimation based on the fixed effects model without using macroeconomic controls in order to preserve as many degrees of freedom. Omission of macroeconomic controls should not have a significant impact on the model assessment, given that the period covered by the sample is relatively short and relates to the economic crisis, when the majority of macroeconomic variables stagnated or recorded a slight decrease (National Bank of Serbia, 2015).

Prior to assessment, regressors were correlated in order to determine whether there is a problem of multicollinearity. Correlation matrix of regressors shown in Table 1, does not indicate the existence of an extremely high correlation between any of the pairs of regressors. The highest values of correlation coefficients were measured for the centralization of collective bargaining and regulation of hiring and firing, i.e. mandatory employment costs, respectively, but they are still lower than $70 \%$. 
Pavlović D. et al.: Relationship of the Youth Unemployment and Determinants...

Table 1. Correlation matrix of regressors

\begin{tabular}{|l|l|l|l|l|l|}
\hline & hr_mw & h_f_r & ccb & h_r & mc_wd \\
\hline hr_mw & 1.000 & & & & \\
\hline h_f_r & 0.424 & 1.000 & & & \\
\hline ccb & 0.197 & 0.574 & 1.000 & & \\
\hline h_r & -0.109 & 0.479 & 0.549 & 1.000 & \\
\hline mc_wd & -0.134 & -0.152 & 0.004 & 0.071 & 1.000 \\
\hline
\end{tabular}

Source: Authors'

First, three models are estimated, for which the youth unemployment rate is an indicator of unemployment in three variants: overall (ur_15_24), for male (m_ur_15_24) and female population (f_ur_15_24). Due to the incomplete set of data on youth unemployment for 11 Balkan countries, the number of observations was reduced from 77 to 60 . All regressions were estimated based on the model with fixed effects, using the method of least squares on the transformed data from which the impact of time-invariant omitted variables was eliminated. In addition, the statistical significance of regression coefficients is calculated based on Huber-White's corrected variancecovariance matrix of residuals. The results of the estimated regression models are shown in Tables 2-4:

Table 2. Results

\begin{tabular}{|l|l|l|l|l|l|l|}
\hline ur_15_24 & coef. & std. err. & $\mathrm{t}$ & $\mathrm{p}>|\mathrm{t}|$ & \multicolumn{2}{l|}{ [95\% conf. interval] } \\
\hline hr_mw & 2.196 & 1.633 & 1.34 & 0.208 & -1.442 & 5.834 \\
\hline h_f_r & -4.996 & 1.879 & -2.66 & 0.024 & -9.182 & -.8103 \\
\hline ccb & 6.819 & 2.485 & 2.74 & 0.021 & 1.283 & 12.355 \\
\hline h_r & 2.726 & 1.055 & 2.58 & 0.027 & .376 & 5.075 \\
\hline mc_wd & -5.552 & 2.878 & -1.93 & 0.083 & -11.964 & .859 \\
\hline cons & 20.608 & 16.702 & 1.23 & 0.245 & -16.606 & 57.821 \\
\hline Note: No. of observations 60; R-Squared 0.42 \\
\hline
\end{tabular}

Source: Authors'

Table 3. Results

\begin{tabular}{|l|l|l|l|l|l|l|}
\hline m_ur_15_24 & coef. & std. err. & $\mathrm{t}$ & $\mathrm{p}>|\mathrm{t}|$ & [95\% conf. interval] \\
\hline hr_mw & 2.189 & 1.627 & 1.35 & 0.208 & -1.435 & 5.814 \\
\hline h_f_r & -5.237 & 2.215 & -2.36 & 0.040 & -10.173 & -.300 \\
\hline ccb & 6.562 & 2.867 & 2.29 & 0.045 & .175 & 12.949 \\
\hline h_r & 2.761 & 1.104 & 2.50 & 0.031 & .301 & 5.220 \\
\hline mc_wd & -5.713 & 2.958 & -1.93 & 0.082 & -12.305 & .879 \\
\hline cons & 23.352 & 18.430 & 1.27 & 0.234 & -17.713 & 64.418 \\
\hline Note: No. of observations 60; R-Squared 0.38 \\
\hline
\end{tabular}

Source: Authors' 
Pavlović D. et al.: Relationship of the Youth Unemployment and Determinants...

Table 4. Results

\begin{tabular}{|l|l|l|l|l|l|l|}
\hline m_ur_15_24 & coef. & std. err. & t & p>|t| & [95\% conf. interval] \\
\hline hr_mw & 2.197 & 1.637 & 1.34 & 0.205 & -1.449 & 5.844 \\
\hline h_f_r & -4.718 & 1.513 & -3.12 & 0.011 & -8.089 & -1.347 \\
\hline ccb & 7.293 & 1.989 & 3.64 & 0.004 & 2.861 & 11.725 \\
\hline h_r & 2.638 & .984 & 2.68 & 0.023 & .446 & 4.831 \\
\hline mc_wd & -5.208 & 2.748 & -1.9 & 0.087 & -11.351 & .914 \\
\hline cons & 15.706 & 14.895 & 1.05 & 0.310 & -17.482 & 48.895 \\
\hline Note: No. of observations 60; R-Squared 0.45 \\
\hline
\end{tabular}

Source: Authors'

The results of the evaluation shown in Tables 2-4 indicate the uniformity of the estimated regression coefficients in intensity, direction and statistical significance of the influence on the dependent variables, which implies that the gender structure of the younger population has no great significance in the mechanism of the effect of labour market flexibility on unemployment. In theory, greater flexibility in the labour market evidently leads to lower unemployment, which indicates a negative sign of regression coefficients. This expectation is confirmed in the case of the hiring and firing regulation, and mandatory costs of dismissals, whose regression coefficients are negative and statistically significant at a significance level of $5 \%$ and $10 \%$, respectively. Two other statistically significant impacts come from the centralization of collective bargaining and mandatory employment costs, which is contrary to expectations. However, the impact of centralization of collective bargaining should be interpreted with caution, since a higher level of centralization does not necessarily mean a stronger negotiating power. The same applies to the mandatory employment costs (taxes and contributions), which represent only the element of the total tax and social policy, and may be partly neutralized if the Government uses some other system of incentives for employment financed through fiscal revenues. Another possible explanation for this anomaly is more technical in nature and relates to the possible emergence of so-called spurious correlations, which can sometimes occur in small samples. Out of the remaining regressors, the amount of the minimum wage has no significant effect on youth employment. Explanatory power of the estimated regression models is solid and is around $40 \%$.

Given the relatively small sample and the reduced number of observations in the case of youth unemployment, in order to test the robustness and difference of the impact of the labour market flexibility indicators, the estimation was repeated using three indicators of general unemployment rate of the economically active population: overall (ur_15_m), for male 
Pavlović D. et al.: Relationship of the Youth Unemployment and Determinants...

(m_ur_15_m) and female population (f_ur_15_m), for the entire sample with 77 possible observations. The results are shown in the Tables $5-7$.

Table 5. Results

\begin{tabular}{|l|l|l|l|l|l|l|}
\hline ur_15_m & coef. & std. err. & $\mathrm{t}$ & $\mathrm{p}>|\mathrm{t}|$ & \multicolumn{2}{l|}{$[95 \%$ conf. interval] } \\
\hline hr_mw & .140 & .699 & 0.20 & 0.844 & -1.416 & 1.698 \\
\hline h_f_r & -2.528 & .597 & -4.24 & 0.002 & -3.859 & -1.198 \\
\hline ccb & 2.395 & 1.178 & 2.03 & 0.069 & -.229 & 5.020 \\
\hline h_r & .921 & .654 & 1.41 & 0.189 & -.537 & 2.379 \\
\hline mc_wd & -2.217 & 1.740 & -1.27 & 0.231 & -6.094 & 1.660 \\
\hline cons & 20.626 & 6.991 & 2.95 & 0.015 & 5.047 & 36.204 \\
\hline Note: No. of observations 77; R-Squared 0.31 \\
\hline \multicolumn{7}{|l}{} \\
\hline
\end{tabular}

Table 6. Results

\begin{tabular}{|l|l|l|l|l|l|l|}
\hline m_ur_15_m & coef. & std. err. & $\mathrm{t}$ & $\mathrm{p}>|\mathrm{t}|$ & \multicolumn{2}{l|}{$[95 \%$ conf. interval] } \\
\hline hr_mw & .069 & .757 & 0.09 & 0.928 & -1.618 & 1.758 \\
\hline h_f_r & -2.988 & .669 & -4.47 & 0.001 & -4.480 & -1.497 \\
\hline ccb & 2.219 & 1.287 & 1.72 & 0.115 & -.649 & 5.088 \\
\hline h_r & .783 & .687 & 1.14 & 0.281 & -.748 & 2.316 \\
\hline mc_wd & -2.253 & 1.789 & -1.26 & 0.237 & -6.240 & 1.734 \\
\hline cons & 25.127 & 7.014 & 3.58 & 0.005 & 9.498 & 40.757 \\
\hline Note: No. of observations 77; R-Squared 0.27 \\
\hline
\end{tabular}

Table 7. Results

\begin{tabular}{|l|l|l|l|l|l|l|}
\hline f_ur_15_m & coef. & std. err. & $\mathrm{t}$ & $\mathrm{p}>|\mathrm{t}|$ & \multicolumn{2}{|c|}{ [95\% conf. interval] } \\
\hline hr_mw & .233 & .629 & 0.37 & 0.718 & -1.168 & 1.635 \\
\hline h_f_r & -1.990 & .593 & -3.35 & 0.007 & -3.312 & -.667 \\
\hline ccb & 2.688 & 1.081 & 2.49 & 0.032 & .279 & 5.097 \\
\hline h_r & 1.069 & .619 & 1.72 & 0.115 & -.311 & 2.450 \\
\hline mc_wd & -2.085 & 1.662 & -1.25 & 0.238 & -5.790 & 1.618 \\
\hline cons & 14.360 & 7.053 & 2.04 & 0.069 & -1.356 & 30.077 \\
\hline Note: No. of observations 77; R-Squared 0.35 \\
\hline
\end{tabular}

Source: Authors'

The results of the regression assessment on the basis of the general unemployment rate provide a somewhat different figure compared to the modelling of youth unemployment rate. While most of the regression coefficients have the same direction, statistical significance was reduced in the case of mandatory hiring and firing costs and to a lesser extent in the centralization of collective bargaining. In fact, two most robust results were negative impact of the hiring and firing regulation, and the absence of influence of the minimum wage policy on unemployment, either overall or youth. 
Pavlović D. et al.: Relationship of the Youth Unemployment and Determinants...

\section{Discussion}

Taking into account all of these limitations of the research that are reflected in the small number of observations, as well as the instability and illogic of some of the estimated regression correlations, it is difficult to draw a greater number of "good" conclusions on the basis of this paper. The most important result is certainly a very robust assessment of the negative impact of the regulation level on employment, both youth and adults. This is in line with the results of Bernal-Verduga et al. (2012) based on regression analysis of a larger sample of 97 countries for the period from 1985 to 2008, where they suggest that the hiring and firing regulation and employment costs have the most significant impact on the unemployment rate.

It is also important to emphasize that the research results implied that the amount of the minimum wage has no significant impact on youth and general unemployment. Unemployed young people in the Balkans are willing to work for lower wages but the others side they don't have job opportunity on the labour market. In developed countries, minimum wages have no significant impact on the employment rate among workers who are at the peak of their service life, especially in developed countries such as the OECD countries (OECD, 1998). On the other hand, based on the results of the survey named "youth expectations when entering the labour market in the Republic of Serbia," young people do not regard low wages as a problem, but the lack of vacancies (Pavlović, Zubović, Zdravković, 2016). For the question "Is salary the only factor important for hiring young employees? ", from the factor analysis, it can see that the econometric models show that salary is not an important factor for employment of people younger than 30. According to the young people's answers and this research, the average salary is less important factor. The young would prefer learning and training over high earnings especially at the beginning of their career.

\section{Conclusion}

Since the onset of the financial crisis in 2008, the high unemployment rate among young people has been one of the most pressing social problems at a global level. Even in countries that are members of the European Union, finding a solution to this problem is among their priorities. The latest statistics show that more than half of the young population in most Western Balkan countries is unemployed (ILO, 2016), which further affects the increase in the informal employment rate (Statistical Office of the Republic of Serbia, 2015; World Bank, 2016). 
Pavlović D. et al.: Relationship of the Youth Unemployment and Determinants...

Given the above facts, it is evident that youth unemployment is a major problem of society that must be interpreted from different aspects, in order to come up with new information and useful insights.

The research results could be used by decision-makers for defining strategies that affect young people and in the field of labour market.

To which extent the changes in legal regulations of employment in the Balkans will affect the reduction in the unemployment rate, can be determined by conducting this study again in the future.

\section{References}

Arandarenko, M. (2011). Tržište rada u Srbiji. Belgrade, Serbia: Faculty of Economics. Arandareno, M., \& Bartlett, W. (2012). Labour Market and Skills in the Western Balkans. Belgrade, Fren- Foundation for the Advancment of Economics. Belgrade, Serbia.

Bernal-Verdugo, L.E., Furceri, D., \& Guillaume, D.M. (2012). Labor Market Flexibility and Unemployment: New Empirical Evidence of Static and Dynamic Effects. IMF Working Papers, 12(64), 1. doi:10.5089/9781463938413.001

Booth, A.L. (2014). Wage Determination and Imperfect Competition. IZA discussion paper, Bonn, 8034,

Cahuc, P., Carcillo, Z., \& Zimmermann, K.F. (2013). The employment of the low-skilled youth in France. IZA Policy Paper,No 64.

Card, D., \& Krueger, A.B. (1994). Minimum Wages and Employment: A Case Study of the Fast-Food Industry in New Jersey and Pennsylvania: Reply. American Economic Review, 84(4), 772-793.

Chuang, Y.C. (2006). The effects of minimum wage on youth employment and unemployment in Taiwan. Hitotsubashi Journal of Economics, Vol. 47, pp. 155167.

Flinn, C.J. (2006). Minimum Wage Effects on Labor Market Outcomes under Search, Matching, and Endogenous Contact Rates. Econometrica, 74(4), 1013-1062. doi:10.1111/j.1468-0262.2006.00693.x

-Fraster Institute, (2016). The Economic Freedom of the World: Annual Report. Revered from https: //www. fraserinstitute. org/resourcefile?nid=10159\&fid $=4821$.

Gorry, A. (2013). Minimum wages and youth unemployment. European Economic Review, 64, 57-75. doi:10.1016/j.euroecorev.2013.08.004

Heckman, J., Lochner, L., \& Taber, C. (1998). Explaining Rising Wage Inequality: Explorations with a Dynamic General Equilibrium Model of Labor Earnings with Heterogeneous Agents. Review of Economic Dynamics, Cambridge, MA: National Bureau of Economic Research; vol 1. doi:10.3386/w6384

-INS. (2014). Migratia internationala a Romaniei. Retrieved from http://www.insse.ro/cms/files/publicatii/pliante\%20statistice/Migratia_international a a Romaniei n.pdf.

-International Labour Organization. (2015). Statistics and databases. Retrieved from http://www.ilo.org/global/statistics-and-databases/lang--en/index.htm. 
Pavlović D. et al.: Relationship of the Youth Unemployment and Determinants...

-International Labour Organization. (2016). Statistics and databases. Retrieved from http://www.ilo.org/global/statistics-and-databases/lang--en/index.htm.

Junankar, P. (2015). The impact of the Global Financial Crisis on youth unemployment. The Economic and Labour Relations Review, 26(2), 191-217. doi:10.1177/1035304615580536

Kelly, E., \& McGuinness, S. (2015). Impact of the Great Recession on unemployed and NEET individuals' labour market transitions in Ireland. Economic Systems, 39(1), 59-71. doi:10.1016/j.ecosys.2014.06.004

Marginean S. (2014). Youth unemployment in Romania: Post-Crisis Challenges, 21st International Economic Conference 2014, IECS 2014, Procedia Economics and Finance, vol. 16, 613-620.

Parey, M. (2009). Vocational Schooling versus Apprenticeship Training: Evidence from Vacancy Data. Unpublished manuscript

Psacharopoulos, G., \& Patrinos, H.A. (2004). Returns to investment in education: a further update. Education Economics, 12 (2),111-134.

Rosen, S., (1972). Learning and experience in the labor market. The Journal of Human Resources, 7 (3), 326-342.

Statistical office of the Republic of Serbia, Labour Force Survey (2015), Retrieved from www.stat.org.rs

Vasile V. (2012). Crisis Impact on Employment and Mobility Model of the Romanian University Graduates. Procedia Economics and Finance, 315-324.

World Bank, Statistics (2016), Retrieved from http://econ.worldbank.org/databas 